\title{
Skridt for Skridt \\ Et diakront perspektiv på kvinders bevægelser
}

AF IdA HersKind

\section{ES S A Y}

uden for tema

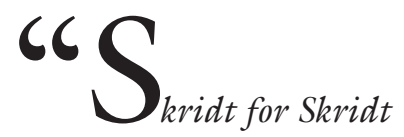

er Kvindesagen gaaet fremad" ("Modgang” 1929). Sådan stod der i 1929 i Kvinden og samfundet - et af kvindebevægelsens mest centrale tidsskrifter. Den danske kvindebevægelse gik fremad, sprængte grænser og nåede nye højder i ligestillingen i slutningen af 1800-tallet og begyndelsen af 1900-tallet. Samtidigt gik kvindekroppen fra at være snøret, strammet og spærret inde af korsettet og i hjemmet til at bevæge sig mere med kroppen og over længere afstande. I dette essay vil jeg foreslå, at betegnelsen kvindebevagelse (i bogstaveligste forstand) også kan referere til, at kvinder begyndte at bevage sig mere. Det teoretisk udgangspunkt er Pierre Bourdieu, og kildematerialet er Kvinden og samfundet i perioderne 1885-89 og 1925-29.2

BOURDIEU OG BEVÆGELSER

Pierre Bourdieus begreb 'den maskuline dominans' betegner det, at mænd er de do- 
minerende i samfundet. Det kommer til udtryk, når vi taler, tænker og handler. Bourdieu mener, at kroppens bevagelser antager en social betydning i konstitueringen af køn og påpeger, at kvindelighed måles efter kunsten at 'gøre sig lille,' modsat mandlighed, som måles efter kunsten at 'gøre sig stor' (Bourdieu 2000: 7). Kvinders positur, kropsholdning, bevægelser og adfærd kalder han et slags 'usynligt indelukke,' der begrænser det territorium, inden for hvilket kvinders kroppe kan bevæge sig og flytte sig, hvorimod mænd med deres kroppe kan optage nærmest ubegrænset plads særligt $\mathrm{i}$ offentlige rum (Bourdieu 2000: 41). På den måde tegner Bourdieu et billede af 'usynlige snore,' der binder kvinders kropsdele sammen og af 'usynlige kridtstreger,' der bestemmer, hvor denne sammenbundne krop må bevæge sig hen. Han mener, at det er de gamle strukturer, der bestemmer forandringens form (Bourdieu 2000: 120). Hvilket betyder, at snorene ikke bare kan klippes over, men at de i stedet gradvist og langsomt slides over. $\mathrm{Og}$ selv når kridtstregerne er næsten udviskede, danner de skabelon for, hvordan de nye skal kridtes op.

Bourdieu pointerer, at ved at være kroppe er mennesker situeret ét sted og kan derfor ikke befinde sig flere steder på en gang. Det gælder både i et fysisk rum og i et relationelt sted, dvs. $\mathrm{i}$ form af en position $\mathrm{i}$ samfundet eller i rangordenen.

Det borgerlige ideal i 1800-tallet, hvor husfruen værner om den indre verden $\mathrm{i}$ hjemmet og manden om den ydre i form af sit arbejde, blev afspejlet i sproget: En 'offentlig kvinde' var nærmest sproglig identisk med en prostitueret, mens en 'offentlig mand' var noget ærefuldt (Hagemann 1994: 18). Da den formelle ligestilling mellem kønnene blev indført i 1925 i Danmark, betød det dog ikke en umiddelbar ændring af forholdet mellem kvinder og mænd på arbejdsmarkedet. Andelen af hjemmegående kvinder ændrede sig ikke ret meget: I 1880 var $54 \%$ kvinder beskæf- tiget i hjemmet og i 1940 var andelen 48\% (Rosenbeck 1990: 304). Det borgerlige kvindeideal fra 1800-tallet blev blot erstattet af idealet 'husmoderen' (Rosenbeck 1990: 282). Der er således ikke belæg for, at indførelsen af den formelle ligestilling medførte en ændring i forholdet mellem kvinde/mand og privat/offentlig. Derfor er der behov for at undersøge kvindebevægelsen, ikke bare ud fra juridiske og erhvervsmæssige præmisser, men også ud fra et kropsbevidst eller performativt perspektiv i konkret forstand, nemlig Bourdieus, i forsøget på at etablere en mere dynamisk forståelse af begrebet 'kvindebevægelse'.

\section{BEVÆGELSER MED KROPPEN}

Kvindekroppens bevægelsesfrihed var begrænset af tidens mode i 1885-89, som dikterede et stramt korset og lange, tunge kjoler. Denne mode blev i høj grad problematiseret i Kvinden og Samfundet, og der var en stor interesse for at indføre en såkaldt 'reformdragt', som skulle være behagelig at bære og øge bevægelsesmulighederne, men det blev aldrig normen i perioden, og skribenten Lovise Hansen spørger retorisk i 1889:

Var det nu ikke ogsaa paa Tide at vi turde vise Verden, at vi danske Kvinder tør klæde os efter eget Tykke uden først at indhente Tilladelse i Paris? ("Fra Udenbys Venner" 1889).

Og det var ikke bare kroppens bevægelighed, der blev hæmmet af "den franske Modes Tyranni," men også kroppens indre funktioner led under klædedragternes konvention:

[...]Mavesækken, Leveren og de andre bløde Organer, som sammenpresses af Snørelivet, kunne ikke gjøre deres Gjerning(...). Det, at Aandedrættet ogsaa maa gaa for sig uden den fulde Hjælp af Mellemgulvs- og Ribbensbevægelser, saa man først om Aftenen efter Afklædning kan aande rigtig dybt ("Hvem skal 
tage Spørgsmaalet om en Reform af den kvindelige Klædedragt i sin Haand?” 1887).

Selv når kvinder skulle motionere, var de begrænset og underlagt normer for hvilke bevægelser, der blev anerkendt som feminine. En artikel fra 1889 hedder "Kvindesport” og omhandler hvilke sportsgrene der var passende for kvinder. Der lægges vægt på, at sport for kvinder skal være graciøs. Af sportsgrene, som var passende for kvinder, nævnes tennis, langbold, gymnastik, ridning og cykling. Samt den mulighed at cricket kunne blive en fremtidssport ("Kvinde-sport" 1889).

I 1925-29 blev der ikke længere klaget over moden og i en reklamereannonce for korsetter, făr man oplyst at korsetterne er elastiske og “[...] overordentligt behagelig at bære." ("Annoncer" 1925) Som Bourdieu påpeger, er det de gamle strukturer, der bestemmer forandringernes form: Korsettet bliver ikke afskaffet, men modificeret - eller 'snorene' løsnet. I 1920'erne er der mere fokus på at dyrke sport af sundhedsmæssige årsager. $\mathrm{Og} \mathrm{i}$ en artikel fra 1926 roser Kvinden og samfundet gymnastiklærerinde Elly Kühle for at have fået tilladelse til at undervise i gymnastik i et kvindefængsel, da det ellers kun har været anvendt i mandefængsler ("Gymnastik indført i danske Kvindefængsler" 1926). Kvindekroppen kan i dette tilfælde bevæge sig, selv når den er blevet spærret inde.

\section{BEVÆGELSER TIL NYE RUM}

Med 'nye rum' mener jeg rum, som Kvinden og samfundet anser for nye, og som derfor bliver nævnt i forbindelse med en nyhed. Toppen af Mont Blanc er et eksempel på et nyt rum, der blev indtaget. Det oplyses i 1887, at kvinder har besteget bjerget ("Fra Indland og Udland" 1887 no. 8) og i 1888 nævnes det som en nyhed, at to finske kvinder har foretaget en naturvidenskabelig ekspedition til Finlands "fjerne egne" ("Fra Indland og Udland" 1888 no. 4)
Klasseværelset og operationsstuen er eksempler på rum, der bliver mere tilgængelige for kvinder rent professionelt. Når kvinder registreres i nye rum - om det så er på den anden side af jorden - bringes det som en nyhed, som meddelelsen om, at Kina har fået en kvindelig læge 1886 ("Fra Indland og Udland" 1888 no. 1).

Det har stadig en nyhedsværdi i slutningen af 1920'erne, når en kvinde indtager et nyt rum- og i denne periode bevæger de sig ud på hidtil ukendte dybder og højder. Man kan læse, at Lady Baily flyver fra England til Sydafrika i 1928 ("Ude Fra" 1928 no. 10). Og da England samme år får sin første kvindelige skorstensfejer, er der oveni købet et fotografi af hende, hvorunder hendes første bedrift står beskrevet: “[...] sammen med en mandelig Skorstensfejer at klatre op ad luftige trappetrin i en Højde af 50 Meter" ("Nyt Udefra” 1927 no. 14). Lige under denne nyhed fortælles der om kvindelige perledykkere i Japan, som svømmer helt ned til 60 fod under havets overflade for at samle perler op. Kvinder bevæger sig op og ned og ud og ind i nye rum, som tidligere kun har været betrådt af mænd.

Dansk Kvindesamfund kæmper for kvinders ret til at bestride nye erhverv og embeder, så det bliver forsat bragt som en nyhed, når det sker. For eksempel da en norsk kvinde bliver rektor i 1926 ("Nyt Udefra" 1926 no. 9), da Danmark får en kvindelige radiovært i 1926 ("Den første -" 1926) og da en kvinde bliver ansat i Vatikanet i 1927 ("Nyt Udefra" 1925 no. 4).

Kvinders pludselige tilstedeværelse under havets overflade, på vinger i luften og med en skalpel i hånden, får en symbolsk betydning for deres sociale position. Bourdieu påpeger, at sociale aktører/kroppe er konstitueret til ét rum, hvilket kan forklare, hvorfor kvinders indtagelse af 'nye rum' havde en nyhedsværdi - 'nye rum' betød nemlig nye sociale positioner. 


\section{BEVÆGELSER I DET OFFENTLIGE RUM}

Der nævnes stort set ingen udflugter eller transportmidler i forbindelse med kvindesagens mødekultur i 1885-89, men det gør der til gengæld i 1925-29. I denne periode er det muligt at få et langt større indblik $\mathrm{i}$ Dansk Kvindesamfunds mødekultur pga. det faste bidrag "Fra Kredsene," hvor de respektive kredse beretter kortfattet om deres aktiviteter. Det er ganske bemærkelsesværdigt, at der i korte beskrivelser af møder eller arrangementer, som højst fylder et par sætninger, ofte eksplicit nævnes hvilke transportmidler der er blevet anvendt. Assens-kredsen afholdt en fest i 1925 og oplyser, at de ældre damer blev kørt hjem i biler ("Fra Kredsene" 1925 no. 3). Tistrupkredsen oplyser, at 130 kvinder deltog på et kursus, hvoraf nogen kom "[...] langvejs fra i Bil, med Tog eller paa Cykle" ("Fra Kredsene" 1925 no. 6). Og på fællesmødet i 1929 "[...] gled store og mindre Automobil-Omnibusser frem og tilbage mellem Nordby og Strandhotellet" ("Fællesmødet" 1929 no. 11).

Der blev arrangeret utroligt mange udflugter af Dansk Kvindesamfund enten som selvstændige arrangementer eller i forbindelse med møder, som fx en "[...] fornøjelig Skovtur" ("Fra Kredsene" 1925 no. 7), en "[...] lille Udflugt ved Hjælp af 14 biler, som Byens Borgere elskværdigt havde stillet til Raadighed," ("Fra Kredsene" 1926 no. $10)$, "[...] en sejltur på fjorden" ("Fællesmødet i Haderslev" 1928 no. 9), en udflugt i Berlin i "[...] komfortable Charabancer" ("Kongressen i Berlin" 1929) eller “[...] en dejlig Tur til Mols i en Rutebil og nogle private Biler" ("Aarhus-Kredsen" 1929). Denne måde at bevæge sig kollektivt på kan opfattes som magtdemonstrationer eller med Bourdieus begreb som 'rummelig positionering.' Men der nævnes også reelle demonstrationer, som ved Kongressen i Paris i 1926:

[... ]onsdag den 2. Juni er det planlagt, at Kongressens Deltagere skal slutte sig til en
Demonstration for Kvinders Stemmeret.

Denne vil foregaa i et sluttet Tog af Automobiler" (“Kongressen i Paris" 1926).

En bil kan muliggøre store bevægelser i det offentlige rum, som ifølge Bourdieu netop er en af de ting, som maskulinitet måles efter. Denne opfattelse kan sammenlæses med hans begreb 'den maskuline dominans' i et eksempel fra samme kongres: "Som Hvilepunkt i Arbejdet var der arrangeret en Udflugt pr. Automobil [...] [vi] nød Opholdet i den friske Luft - og Friheden" ("Kongressen i Paris" 1926). Her bevæger det kvinderne emotionelt at bevæge sig fysisk. Ved at trykke sømmet i bund og 'gøre sig stor' efterligner eller citerer kvinderne mænds (store) bevægelsesmønstre. På den måde løsriver de sig fra den undertrykkende, mandsdominerende struktur, som er beskrevet ved 'den maskuline dominans,' og kvinderne mærker derfor "Friheden", som det udtrykkes.

\section{SNORE LØSNES OG KRIDTSTREGER UDVISKES?}

Ved gennemlæsning af Kvinden og samfundets første årgang fra 1885 noterede jeg kun syv artikler, der omhandlede bevægelse, mens jeg ved gennemlæsning af årgangen fra 1925 noterede mig over 50 artikler. Selvom tidskriftet udkom dobbelt så ofte i 1925, er det stadig bemærkelsesværdigt, hvor meget mere der stod om bevægelser. Undersøgelsen dækker primært de privilegerede kvinder, da tjenestepiger og andre fra arbejderklassen ikke fik spalteplads, men det var også disse privilegerede kvinder, der udgjorde en stor del af kvindebevægelsen (i kraft af deres medlemsskab af Dansk Kvindesamfund). Overordnet set, afspejler undersøgelsen, at disse kvinder bevægede sig mere i slutningen af 1920'erne end 1880'erne. Derudover viser sammenligningen en udvikling i hvordan Kvinden og samfundet skrev om kvinders bevægelser. I 1920'erne blev der i højere grad fokuseret på kvinders 
bevægelse i det offentlige. Og som Bourdieu påpeger, antager kroppens bevægelser en social betydning, hvilket kan forklare hvorfor, at der blev skrevet så meget om udflugter, transportmidler, sport, samt indtagelse af nye rum og erhverv. Alle disse faktorer overskred nemlig de usynlige 'kridtstreger' og 'snore' og fik dermed en symbolsk betydning. Indtagelsen af det fysiske rum, var også en indtagelse af det sociale rum. Hvis maskulinitet måles efter kunsten 'at gøre sig stor' og mænd var de dominerende og magtbesiddende, så er det min påstand, at kvinderne opnåede symbolsk magt ved at efterligne dem og citere deres handlinger ved også at 'gøre sig store.' Dette kan ses som en frigørelse fra 'den maskuline dominans,' og forklare, hvorfor det for eksempel har føltes befriende at køre i bil og været nævneværdigt, når en kvinde klatrede op i en skorsten for at rense den.

Det er interessant, at kvinders formelle ligestilling med mænd og kvinders fysiske bevægelser udvikler sig parallelt. Disse to udviklinger kan opfattes som afhængige af hinandens gensidige udvikling, og dermed pege på et lighedstegn mellem bevægelse og magt; samt mellem bevægelse og frihed.

\section{Noter}

1. Når der henvises til artikler fra Kvinden $O g$ Samfundet er der oplyst artiklens overskift, i stedet for forfatterens navn, da tidsskiftets skribenter ofte ikke er mig bekendt. Ved henvisning til faste indlæg er der yderligere oplyst tidskriftets nummer, så det er muligt at skelne mellem de artikler der har samme overskrift og år.

2. Tidsskriftet Kvinden og samfundet udgives af Dansk Kvindesamfund, som blev stiftet i 1872 af både mænd og kvinder, som karakteriserede sig selv som en del af kvindesagen. Dengang arbejdede Dansk Kvindesamfund især for kvindens ligestilling i ægteskabet og for en forbedring af kvindens kår på arbejdsmarkedet. Materialet for denne artikel består af Kvinden og samfundets udgivelser fra perioderne 1885-89 og 1925-29. Skellet er sat her, fordi tidskriftet udkom for første gang i 1885 , og bliver sammenlignet med perioden 1925-29, fordi den formelle ligestilling mellem kønnene blev gennemført i 1925. Tidskriftet udkom ca. hver måned i 1885-89 og to gange om måneden i 1925-29.

\section{LITTERATUR}

. "Annoncer”, i: Kvinden Og Samfundet 41. årgang, no. 1 (1925).

- Bittmann, Johannes (1929): "Modgang”, i: Kvinden Og Samfundet 45. årgang, no. 9 (1929). - Bourdieu, Pierre (2000): Den maskuline dominans. Pax Forlag, Oslo.

. "Den Første -", i: Kvinden Og Samfundet 42. årgang, no. 11 (1926).

. "Fra Indland Og Udland", i: Kvinden Og Samfundet 3. årgang, no. 8 (1887).

. "Fra Indland Og Udland", i: Kvinden Og Samfundet 4. årgang, no. 2 (1888).

. "Fra Indland Og Udland", i: Kvinden Og Samfundet 4. årgang, no. l (1888).

. "Fra Kredsene", i: Kvinden Og Samfundet 41. årgang, no. 3 (1925).

. "Fra Kredsene", i: Kvinden Og Samfundet 41. åragng, no. 6 (1925).

. "Fra Kredsene", i: Kvinden Og Samfundet 41. åragng, no. 7 (1925).

. "Fra Kredsene", i: Kvinden Og Samfundet 42. årgang, no. 10 (1926).

. "Frllesmødet", i: Kvinden Og Samfundet 45. årgang, no. 11 (1929).

. "Fxllesmødet i Haderslev", i: Kvinden Og Samfundet 44. årgang, no. 9 (1928).

. "Gymnastik Indført i Danske Kvindefængsler", i: Kvinden Og Samfundet 42. årgang, no. 22 (1926).

- Hagemann, Gro, \& Anne Krogstad (1994): Høydeskrekk, kvinner og offentlighet. Ad Notam Gyldendal, Oslo.

- Hansen, Lovise (1889): "Fra Udenbys Venner", i: Kvinden Og Samfundet 5. årgang, no. 6 (1889). . "Hvem Skal Tage Spørgsmaalet Om En Reform Af Den Kvindelige Klædedragt i Sin Haand?”, i: Kvinden Og Samfundet 3 årgang, no. 3 (1887).

. "Kongressen i Berlin", i: Kvinden Og Samfundet 45. årgang, no. 7 (1929).

. "Kongressen i Paris", i: Kvinden Og Samfundet 42. årgang, no. 6 (1926).

. "Kvinde-sport", i: Kvinden Og Samfundet 5. årgang, no. 5 (1889).

. "Nyt Udefra", i: Kvinden Og Samfundet 43. årgang, no. 4 (1925). 
. "Nyt Udefra”, i: Kvinden Og Samfundet 42. årgang, no. 9 (1926).

. “Nyt Udefra”, i: Kvinden Og Samfundet 43. årgang, no. 14 (1927).

- Rosenbeck, Bente (1990): Kvindekøn. Den Moderne Kvindeligheds Historie 1880-1980. Gyldendal, København.
. “Ude Fra”, i: Kvinden Og Samfundet 44. årgang, no. 10 (1928).

. “Aarhus-Kredsen”, i: Kvinden Og Samfundet 45. årgang, no. 9 (1929).

Ida Herskind, stud.mag. i historie 